ROCZNIKI HISTORYCZNE

Rocznik LXXXI - 2015

ANDRZEJ PLESZCZYŃSKI (Lublin)

\title{
Wiadomości Ottona z Fryzyngi i Rahewina o Polsce na tle ich doniesień o wschodnich sąsiadach Niemiec
}

Spośród wszystkich niemieckich tekstów powstałych w XII w. najobszerniejsze, najpełniejsze i najbardziej uporządkowane strukturalnie wiadomości o kraju Piastów oraz jego sąsiadach znajdziemy w monumentalnych dziełach historiograficznych, których autorem był Otto z Fryzyngi, a częściowo jego uczeń Rahewin. Ani u Annalisty Saksona ${ }^{2}$, ani w Rocznikach magdeburskich ${ }^{3}$, nie wspominając już o innych dziełach kronikarskich i annalistycznych pisanych w tym czasie na obszarze Rzeszy, nie znajdziemy podobnego obrazu Europy Środkowej czy jakiegokolwiek kraju tego regionu i jego mieszkańców. Prace biskupa Fryzyngi uznawane są w ogóle za jedne z najważniejszych tekstów w całej historiografii średniowiecznej, a ponieważ powstawały w kręgu dworu władców Rzeszy, można zakładać, że ich treści są reprezentatywne dla opinii niemieckich środowisk elitarnych owych czasów. Przyjrzyjmy się zatem uważniej tym przekazom.

Starsze z dzieł Ottona z Fryzyngi, Chronica sive historia de duabus civitatibus $^{4}$, skomponowane zostało w 1. 1143-1146. Młodsze, Gesta Friderici ${ }^{5}$, nie zostało ukończone; przed swoją śmiercią 22 IX 1158 r., w wieku niespełna 50 lat, Otto zamknął (1157/1158) zaledwie dwie pierwsze księgi. Do 1160 r. pracę dokończył jednak, dodając dwie kolejne księgi, Rahewin, uczeń biskupa historiografa, jego

1 Tekst niniejszy został opracowany przy wsparciu środków projektu Ministerstwa Nauki i Informatyzacji N N108 189638. W szkicowej wersji wygłoszony został na IV Kongresie Mediewistów Polskich w Poznaniu (19-21 IX 2011).

${ }^{2}$ Das Reichschronik des Annalista Saxo, wyd. K. Nass, Monumenta Germaniae historica, Scriptores, t. XXXVII, Hannover 2006.

3 Annales Magdeburgenses, wyd. G. H. Pertz, Monumenta Germaniae historica, Scriptores, t. XVI, Hannover 1859, s. 105-196.

${ }^{4}$ Ottonis episcopi Frisingensis Chronica sive historia de duabus civitatibus, wyd. A. Hofmeister, Monumenta Germaniae historica, Scriptores rerum Germanicarum, Hannover-Leipzig 1912; tekst powtórzony (wraz z niemieckim thumaczeniem) w: Ottonis episcopi Frisingensis Chronica sive historia de duabus civitatibus, wyd. A. Schmidt, W. Lammers, Berlin 1960 (Ausgewählte Quellen zur deutschen Geschichte des Mittelalters. Freiherr vom Stein-Gedächtnisausgabe 16). Dalej cytuję według tego ostatniego wydania.

5 Ottonis et Rahewini Gesta Friderici I. imperatoris, wyd. G. Waitz, B. von Simson, Scriptores rerum Germanicarum, Hannover-Leipzig 1912; tekst powtórzony (z niemieckim thumaczeniem) w: Gesta Frederici seu rectius chronica, wyd. A. Schmidt, F.-J. Schmale, Berlin 1965 (Ausgewählte Quellen zur deutschen Geschichte des Mittelalters. Freiherr vom Stein-Gedächtnisausgabe 17). Dalej cytuję według tego ostatniego wydania. 
kapelan, a zarazem sekretarz i powiernik ${ }^{6}$. Wspomniane dzieła zawierają mnóstwo najróżniejszych wątków i stanowią prawdziwą kopalnię najróżniejszych treści, mogących stać się przedmiotem badań. Nas będzie interesował jedynie drobny ich wycinek, a mianowicie sprawa obecności w tych tekstach Polski i krajów ościennych. Sposób traktowania tych ostatnich przez kronikarzy da nam mocniejsze podstawy do oceny poglądów Ottona z Fryzyngi i Rahewina na kraj Piastów i jego relacje z Rzeszą. Oba wymienione wyżej dzieła można uznać za pewną całość, reprezentującą przede wszystkim wizję historii i świata Ottona jako myśliciela oraz wybitnego arystokraty, w mniejszym zaś stopniu Rahewina, który w swoim pisarstwie zależny był od swojego poprzednika ${ }^{7}$. Wydaje się zatem uzasadnione połączenie rozważań o obu tekstach, oczywiście biorąc pod uwagę ich odrębności, wynikające z innego przesłania i odmiennej genezy, a także różnice w poglądach autorów, gdy tylko się pojawiają.

Chociaż dawniej uważano, że prace Ottona powstały w kręgu dworu Staufów i wyrażały dokładnie wizję świata i nastroje panujące w otoczeniu Fryderyka Barbarossy, to jednak ostatnio udowodniono istnienie pewnej autonomii intelektualnej biskupa Fryzyngi i jego kontynuatora, podbudowanej wysokimi walorami środowiska tamtejszej szkoły katedralnej ${ }^{8}$. Nie ulega jednak wątpliwości, że oba wspomniane dzieła powstawały w jakimś związku z dworem cesarskim. Kronika albo historia dwóch państw to utwór przesiąknięty koncepcją św. Augustyna, pesymistyczny, widzący obecność i triumfy szatana w doczesności, chiliastyczny, gdyż lokuje tę współczesność u schyłku świata9. Utwór przekazał Fryderykowi I sam Rahewin na polecenie Ottona w 1157 r. Dzieło, nieco dystansujące się od instytucji cesarstwa, musiało znaleźć niezbyt przychylne przyjęcie u władcy i ludzi z jego otoczenia. Otto zdecydował się więc, jak się wydaje, w trybie niejako ekspresowym skomponować utwór na wskroś odmienny, jeśli chodzi o sposób prezentacji najwyższej intencjonalnie

${ }^{6}$ Podstawowe informacje o autorze i jego dziele w hasłach encyklopedycznych: K. S chnith, Otto von Freising, w: Lexikon des Mittelalters, t. VI, Stuttgart 2000, kol. 1581-1583; Otto von Freising, w: Medieval Germany. An Encyklopedia, wyd. J. M. Jeep, New York - London 2001, s. 594 n.; szerzej o autorze: H.-W. G o et z, Das Geschichtsbild Ottos von Freising. Ein Beitrag zur historischen Vorstellungswelt und zur Geschichte des 12. Jahrhunderts, Köln 1984; R. D e u t in g e r, Rahewin von Freising. Ein Gelehrter des 12. Jahrhunderts, Hannover 1996 (Schriften der MGH 47); M. G i e s e, Über die 'Gesta Frederici' Ottos und Rahewins von Freising. Anmerkungen zur Editions- und Überlieferungsgeschichte, Mitteilungen des Instituts für Österreichische Geschichtsforschung 119, 2011, nr 3-4, s. 311-330.

7 R. D e u t i n g e r, Rahewin, s. 25 n.; K. F. M or r i s o n, Otto of Freising's quest for the hermeneutic circle, Speculum 55, 1980, nr 2, s. 207-236, tu s. $208 \mathrm{n}$.

${ }^{8}$ R. D e u t i n g e r, Rahewin, s. 12; J. M a ß, Das Bistum Freising im Mittelalter, München 1986; także: J. J a k u b o w s k a, Koncepcja państwa i Kościoła w historiozoficznej doktrynie Ottona z Freisingu, Studia Mediewistyczne 11, 1970, s. 3-71, tu s. 5-6.

9 J. K o c h, Die Grundlagen der Geschichtsphilosophie Ottos von Freising, w: Geschichtsdenken und Geschichtsbild im Mittelalter, Darmstadt 1965, s. 247-277; H.-W. G o e t z, Das Geschichtsbild, s. 243 n.; J. J a k u b o w s k a, Koncepcja, s. 9 n.; A. C la s s e n, Mauritius von Craûn and Otto von Freising's „The Two Cities”: 12th- and 13th-century scepticism about historical progress and the metaphor of the ship, The German Quarterly 79, 2006, nr 1, s. 28-49. 
władzy świeckiej w ówczesnym chrześcijaństwie zachodnim. Taka jest, uważa się, w pewnym oczywiście uproszczeniu, geneza Czynów Fryderyka ${ }^{10}$.

Treści dzieła zawsze w pewien sposób związane są ze światopoglądem i pochodzeniem autora, dlatego naszą analizę zacząć należy od zastanowienia się nad osobami biskupa Fryzyngi i jego kontynuatora. Z pewnością Rahewin znajdował się w głębokim cieniu Ottona, który pochodził z elity społecznej ówczesnej Rzeszy. Biskup nasz był mianowicie synem margrabiego austriackiego Leopolda III Świętego (Pobożnego) z rodu Babenbergów i Agnieszki z Waiblingen, córki cesarza Henryka IV. Nie wyczerpuje to jednak koligacji kronikarza. Dzięki bowiem przyrodniemu rodzeństwu, zrodzonemu z pierwszego małżeństwa matki z księciem szwabskim Fryderykiem I z rodu Staufów, Otto był bliskim krewnym cesarza Fryderyka Barbarossy. Ojciec tego ostatniego, książę szwabski Fryderyk II, był wszak przyrodnim bratem biskupa, podobnie zresztą jak i poprzednik Barbarossy na tronie niemieckim, Konrad III ${ }^{11}$. Istotne były też więzy powinowactwa łączące Ottona, poprzez małżeństwa jego licznego rodzeństwa, z dynastami środkowoeuropejskimi. Najstarszy brat biskupa, margrabia austriacki Leopold IV (1136-1141), żonaty był z Marią księżniczką czeską, której ojcem był Sobiesław I (1125-1140), a matką - Adlejta, córka węgierskiego Almosa, króla Chorwacji (1091-1127) ${ }^{12}$. Młodsza siostra Ottona, Agnieszka, została z kolei w 1125 r. żoną księcia polskiego Władysława II Wygnańca (1138-1146, zm. 1159) ${ }^{13}$. Kolejną siostrę Gertrudę wydano w 1140 r. za czeskiego Władysława II (księcia w 1. 1140-1158, a potem króla do 1174 r.) $)^{14}$. Przypuszczać zatem można, że kronikarz o takich koligacjach otrzymywał - np. w trakcie zwyczajowych odwiedzin dworu cesarskiego i dworów arystokracji Rzeszy - najświeższe i miarodajne informacje o krajach ościennych. Warto też wspomnieć, że stolica diecezji Ottona dysponowała jedną z lepszych szkół katedralnych w ówczesnych Niemczech.

Trudno powiedzieć, jaki dostęp do wiedzy o ówczesnym świecie - prócz szkoły i dworu biskupa - miał natomiast Rahewin, który był postacią o znacznie skromniejszym pochodzeniu. Wiadomo o nim niestety mało, a przy tym większa część informacji pochodzi z jego własnego dzieła. Przyjmuje się obecnie, że wywodził się raczej ze średnich warstw społecznych, konkretnie z kościelnych ministeriałów, dzierżących dobra w okolicach Fryzyngi ${ }^{15}$. Wieloletnia praca Rahewina przy boku Ottona (przynajmniej od 1144 r.) i bardzo dobre wykształcenie, jakie zdradza komponowany przez niego tekst, pozwalają przypuszczać, że obu autorów łączyła pewna

${ }^{10}$ R. D e u t in g e r, Rahewin, s. 26; S. B a g g e, Ideas and narratives in Otto of Freising's 'Gesta Frederici', Journal of Medieval History 22, 1996, s. 345-377, tu s. 348 n.

${ }^{11}$ O koligacjach Ottona więcej F. S c h w a r z b a u e r, Geschichtszeit. Über Zeitvorstellungen in den Universalchroniken Frutolfs von Michelsberg, Honorius' Augustodunensis und Ottos von Freising, Berlin 2005 (Orbis mediaevalis. Vorstellungswelten des Mittelalters 6), s. 48.

${ }^{12}$ K. L e c hn e r, Die Babenberger, Wien 1975, s. 143 n.

${ }^{13}$ K. J a s i ń s k i, Rodowód Piastów śląskich, wyd. 2, Kraków 2007, s. 58-59.

${ }^{14}$ L. P o 1 a n s k ý, Přemyslovská dynastie. Soupis členů původního českého panovnického rodu, w: Přemyslovci. Budování českého státu, Praha 2009, s. 541-573, tu s. 558; J. Ž e m 1 i č k a, Křižovatky Vladislava II. Co mohl či nemohl druhý český král, w: Vladislav II. druhý král z Přemyslova rodu. K 850. výročí jeho korunovace, Praha 2009, s. 17-27, tu s. 17-18.

${ }^{15}$ R. D e u t ing e r, Rahewin, s. 7 n.; W. Wa t t e n b a c h, F.-J. S c h m a le, Deutschlands Geschichtsquellen, t. I, Darmstadt 1971, s. 60 n. 
ogólna wspólnota myśli charakterystyczna przy tym dla ośrodka intelektualnego we Fryzyndze, ważnego w ówczesnej Rzeszy. Uzasadnia to dodatkowo możliwość łączenia w niniejszym szkicu analizy dzieł obu autorów.

Wydawać by się mogło, że wskazane wyżej koneksje rodzinne dziejopisarza wraz ze świadomością dobrego dostępu do wiedzy o świecie, funkcjonującej w środowiskach dworskich ówczesnej Rzeszy, sprawiały, że Europa Środkowa nie stanowiła dla samego Ottona, a także i Rahewina, jakiejś terra incognita, a wykład o jej krajach będzie stosunkowo obszerny i będzie można w nim odnaleźć coś z osobistych doświadczeń i poglądów kronikarza, coś co poświadczałoby kontakty z ludźmi odwiedzającymi ten region. Przypuszczenie to dodatkowo uzasadnia położenie Fryzyngi - stolica biskupia Ottona znajdowała się przecież w samym sercu Bawarii, stosunkowo blisko granic z Czechami i Węgrami. Zobaczmy zatem, jak wygląda ta kwestia $\mathrm{w}$ rzeczywistości.

Przegląd tekstów autorów fryzyngskich zacznijmy od poświęconych Polsce ustępów starszego z dzieł Ottona. Tu niestety spotka nas zawód. W Kronice informacje o kraju Piastów są lakoniczne, znacznie uboższe od tych, które dotyczą Czech czy Węgier. Wszystkie są też rozproszone i trudno znaleźć klucz, według którego autor je wprowadzał. Wydaje się, że doborem rządził przypadek, wynikający z dostępu Ottona do starszych tekstów, które kompilował, oraz umieszczania wybranych wiadomości w porządku (głównie chronologicznym) zasadniczej narracji, poświęconej przede wszystkim dziejom cesarstwa ${ }^{16}$. Tym bardziej jednak warto przyjrzeć się sprawie i pokusić się o poszukanie jakichś cech ogólnych, stałych tendencji w oglądzie Polski i wschodnich sąsiadów Rzeszy, który utrwalono w Kronice. W naszej analizie postępować będziemy, idąc za układem narracji dzieła, według porządku chronologicznego. Już pierwsza interesująca nas wiadomość uświadamia, jak spekulatywna była konstrukcja historiograficzna tworzona przez Ottona. Otóż we fragmencie wymieniającym ziemie będące we władaniu Karola Wielkiego znajdziemy informację, że nie zostały przezeń opanowane ani Polska, ani Czechy, Węgry, Dalmacja, Brytania, ani też inne jeszcze prowincje, które miały się znajdować wcześniej pod panowaniem rzymskim albo później niemieckim ${ }^{17}$. Z pozoru mogłoby się zdawać, że chodziło o zapis pewnej tradycji historycznej ${ }^{18}$, ale kontekst narracji całego dzieła przekonuje, że w oczach Ottona ziemie wchodzące w skład państwa Karola Wielkiego były generalnie lepsze od innych - na nich wszak w sposób szczególny ziszczał się boski

${ }^{16}$ S. B a g g e, German historiography and the twelfth-century renaissance, w: Representations of Power in Medieval Germany, 800-1500, Turnhout 2006 (International Medieval Research 16), s. 165-188, zwł. s. 180 n.; zob. także F.-J. S c h m a l e, Mentalität und Berichtshorizont, Absicht und Situation hochmittelalterlicher Geschichtsschreiber, Historische Zeitschrift 226, 1978, s. 1-16.

${ }^{17}$ Ottonis Chronica, V 32, s. 422.

${ }_{18}$ Niekoniecznie jednak dominującej, ponieważ powstawały wówczas w Niemczech teksty, w których pisano o podległości Polski imperium Karola Wielkiego - tak jest np. w staroniemieckim przekładzie (dość luźnym) Pieśni o Rolandzie, dokonanym przez „księdza Konrada" prawdopodobnie w Ratyzbonie (Das Rolandslied des Pfaffen Konrad, wyd. C. Wesle, P. Wapnewski, Tübingen 1985, s. 92, w. 1772, s. 248, w. 6849); o przekazie tym zob. szerzej G. L a b u d a, Źródła, sagi i legendy do najdawniejszych dziejów Polski, Warszawa 1960, s. $206 \mathrm{n}$. 
plan historii ${ }^{19}$. Pozostawienie pewnych obszarów poza terenem predestynowanym do roli areny wydarzeń najważniejszych dla dziejów świata (tak jak pojmował je Otto) dość jednoznacznie oznacza ich peryferyjność czy po prostu niższy status. I jest tak, nawet jeśli wedle autora obecnie Polska (Polonia) oraz Czechy i inne ziemie regionu są prowincjami cesarstwa Fryderyka Barbarossy, które miało być obszarem centralnym całej Christianitatis.

Następna wzmianka wiążąca się z Polską dotyczy rzekomego podboju tego kraju przez Henryka II ${ }^{20}$, co wydaje się mechanicznym przeniesieniem informacji żywotów tego cesarza ${ }^{21}$, przygotowywanych z myślą o kanonizacji (dokonanej w 1146 r.). Domysł ów potwierdza fakt, że w innym miejscu Kroniki napisano o przewagach wojennych Henryka „w Niemczech, Czechach, Italii i Apulii”22, nie wspominając tym razem o Polsce. Wydaje się, że Otto, kompilując wzmianki różnych tekstów, nie zawsze panował konceptualnie nad materiałem dotyczącym słabiej znanych mu obszarów. Wskazuje na to ponadto chociażby różny sposób zapisu nazwy kraju Piastów w całej kronice (Polonia, Polania, Polunia), a także częsty brak imion książąt albo ich przekręcania i mylenie. Wyjątkiem jest tu fragment dotyczący Bolesława Chrobrego z poprawnym zapisem: Bolizlaus Poluniorum dux. Otto wiedział o nim, że na początku panowania Konrada II chciał się oddzielić od Rzeszy i ogłosić królem, ale zmarł ${ }^{23}$. Jego syn Mieszko (też opatrzony tam imieniem - Misicho - pewnie dlatego, że o jego koronacji donosiły liczne teksty niemieckie ${ }^{24}$ ) poszedł w ślady ojca i wypędził swego brata Ottona. Król Konrad jednak wyruszył do Polski, aby poskromić krnąbrnego, pomścić krzywdy Rzeszy i przywrócić wygnańca ${ }^{25}$. Tak samo jak starsze teksty, Otto donosił dalej, że Mieszko nie mógł oprzeć się sile króla niemieckiego, stracił insygnia królewskie i uciekł do czeskiego Udalryka. Kronikarz zaznaczył, jakoby książę czeski chciał uchodźcę przekazać władcy niemieckiemu, aby odzyskać jego łaskę, ale ten ostatni w swej szlachetności odmówił wiarołomnemu Czechowi, łamiącemu prawa gościnności. W tym czasie władzę w Polsce przejąć miał Mieszkowy brat, Otto. Diadem, który jego ojciec bezprawnie kazał sobie sporządzić na hańbę Rzeszy ${ }^{26}$, nowy pan kraju przesłał władcy niemieckiemu i podporządkował się w pełni jego zwierzchności. Książę Otto zginął jednak wkrótce,

${ }^{19}$ H.-W. G o e tz, Das Geschichtsbild, s. 36 n.

${ }^{20}$ Ottonis Chronica, VI 28, s. 472 n. Inne średniowieczne teksty niemieckie przypisywały temu władcy nawet nawrócenie Polski i Węgier - D. B u s c h in g e r, Deutsch-polnische Wechselbeziehungen im Mittelalter, w: Deutsche Polenliteratur, Wrocław 1991 (Acta Universitatis Wratislaviensis nr 1297, Germanica Wratislaviensia 42), s. 45-53, tu s. 47.

${ }^{21}$ Die 'Vita sancti Heinrici regis et confessoris' und ihre Bearbeitung durch den Bamberger Diakon Adelbert, wyd. M. Stumpf, Monumenta Germaniae historica, Scriptores, t. LXIX, Hannover 1999, s. 237; zob. także S. B a g g e, German historiography, s. 177 n.

22 Ottonis Chronica, VI 27, s. 470.

${ }^{23}$ Tamże, VI 28, s. 472.

${ }^{24}$ Ch. L ü b k e, Regesten zur Geschichte der Slaven an Elbe und Oder (vom Jahre 900 an), t. I-V, Berlin 1984-1988, tu t. IV, s. 129 n., nr 576.

25 Ottonis Chronica, VI 28, s. 472 n.: rex tam profugum in patriam reducturus, quam de contumace regni iniuriam vindicaturus in Poluniam procinctum movet.

${ }_{26}$ Tamże, s. 474: ad ignominiam regni illicie fecerat. Zob. G. L a b u d a, Mieszko II król Polski (1025-1034). Czasy przełomu w dziejach państwa polskiego, Kraków 1992, s.78 n. 
skrytobójczo zamordowany przez jednego ze swoich dworzan. Teraz Mieszko, dawny król, a obecny wygnaniec, zjawił się przed władcą Rzeszy z prośbą o pomoc, która częściowo została spełniona. Kraj podzielono na trzy części i za wstawiennictwem żony Konrada jedną z nich otrzymał właśnie Mieszko. „Od tej pory prowincja owa znana jest $\mathrm{z}$ tego, że podporządkowana jest naszym królom i płaci im trybut" - konkluduje kronikarz ${ }^{27}$. Wydarzenia te nie zostały datowane, ale następne zapisy zdradzają $_{2}^{28}$, że Otto wiązał je z 1028 r. i różnymi wystąpieniami niemieckich możnych przeciw Konradowi II, jakie w istocie miały miejsce w szerszym okresie od 1025 aż po 1030 r. ${ }^{29}$ Kontekst ten świadczy chyba, że wypadki polskie stanowiły dla kronikarza tylko część wewnętrznych kłopotów Konrada II. Przytoczony opis w gruncie rzeczy jest skróconą kompilacją kilku starszych tekstów niemieckich, zwłaszcza Wipona i Roczników hildesheimskich ${ }^{30}$, ale jednak umieszczenie wiadomości w takiej, a nie innej formie poświadcza - może nawet nieświadomy - stosunek autora do oceny stosunków między Polską a Rzeszą. Według kronikarza kraj Piastów podlegać miał królestwu niemieckiemu. Cytowana uwaga zamyka dla Ottona problem polskich koronacji. Potem nie wspomina już np. ani słowem o „krnąbrności” Bolesława Śmiałego, o której tak rozpisywał się Lampert z Hersfeldu ${ }^{31}$.

Kolejna w Kronice Ottona wzmianka dotycząca Polski również związana jest z kwestią podległości państwa piastowskiego Niemcom. Otto napisał mianowicie o spotkaniu cesarza Lotara z Supplinburga z Bolesławem Krzywoustym w Merseburgu w 1135 r. ${ }^{32}$ Uczynił to jednak w specyficzny sposób: władca Rzeszy miał bowiem niejako po drodze, gdzieś w Saksonii, spotkać bezimiennego księcia polskiego (Polanorum ducem). Przybył on do Lotara z bogatymi darami, ale cesarz nie chciał go przyjąć, zanim nie zapłaci mu zaległego trybutu za 12 lat (po 500 grzywien rocznie). Gdy Bolesław to uczynił, monarcha niemiecki przyjął od niego hołd z Rugii i z Pomorza oraz zapewnił sobie jego trwałe podporządkowanie ${ }^{33}$. Miarę imperialnego

27 Ottonis Chronica, s. 474.

${ }^{28}$ Ottonis Chronica, VI 28-29, s. 474.

${ }^{29}$ H. W o 1 fr a m, Konrad II. 990-1039. Kaiser dreier Reiche, München 2000, s. 89 n.

30 G. L a b u d a, Mieszko II, s.78 n.; Ch. L ü b k e, Regesten, t. IV, s. 153-155, nr 599-600.

31 Lamperti monachi Hersfeldensis Opera, wyd. O. Holder-Egger, Scriptores rerum Germanicarum, Hannover 1894, s. 284 n.: Dux Polenorum, qui per multos iam annos regibus Teutonicis tributarius fuerat, cuiusque regnum iam olim Teutonicorum virtute subactum atque in provinciam redactum fuerat - - regiam dignitatem regiumque nomen sibi usurpavit, diadema imposuit atque ipso die natalis Domini a XV episcopis in regem est consecratus; zob. W. Eg g e rt, Regna, partes regni, provinciae, ducatus. Bemerkungen zu Reichbennenungen und -auffassungen in ,deutschen” Geschichtswerken des 10. und 11. Jahrhunderts, Mitteilungen des Instituts für österreichische Geschichtsforschung 104, 1996, s. 237-251.

${ }^{32}$ Ottonis Chronica, VII 19, s. 530. O szczegółach zjazdu i kontekście politycznym zob. Z. D a l ew sk i, Kaiser Lothar III., Soběslav I. von Böhmen und Bolesław III. von Polen auf dem Hoftag in Merseburg im Jahre 1135, Zeitschrift für Ostmitteleuropa-Forschung 50, 2001, s. 317-336; G. L a b u d a, O stosunkach prawnopublicznych między Polską a Niemcami w połowie XII wieku (Merseburg - 1135, Kaina - 1146, Krzyszkowo - 1157), Czasopismo Prawno-Historyczne 25, 1973, z. 1, s. 25-60.

33 Ottonis Chronica, s. 530: de Pomeranis et Rugis dominium sibi faceret subiectionemque perpetuam sacramento firmaret. Zob. J. H a u z iń s k i, Polska a Królestwo Niemieckie w II połowie XII wieku, w: Polska-Niemcy w średniowieczu, Poznań 1986, s. 137-155, tu 
znaczenia Lotara podnosił fakt, że wtedy też, zdaniem Ottona, król Danii (również bezimienny) niósł przed cesarzem miecz, a od przestraszonego króla węgierskiego (też nienazwanego z imienia) władca Rzeszy otrzymał kosztowne prezenty. Całość zapisu jest oczywiście konstrukcją zbudowaną (z perspektywy mniej więcej 20 lat) na podstawie dostępnych kronikarzowi materiałów - te jednak posiadały dane o imionach władców podporządkowujących się Lotarowi. Forma zapiski zdradza zatem dość protekcjonalny stosunek biskupa Fryzyngi do owych panów umizgających się cesarzowi.

Niemieckie przewagi nad mieszkańcami Europy Środkowej Otto podkreślił i w następnym wiążącym się z Polską fragmencie Kroniki. Otóż książę tego kraju, znowu nienazwany z imienia (chodzi o Bolesława Krzywoustego), wmieszał się w konflikt dynastyczny na Węgrzech, stając po stronie Borysa syna Kolomana przeciwko Beli synowi Almosa. Belę poparli jednak margrabia Leopold III (nawiasem mówiąc, brat naszego kronikarza), a gdy w bitwie (na rzeką Sajó w 1132 r.) Polacy (Poluni) i Węgrzy Borysa poznali po mowie, że przeciwnika wspierają Niemcy (Teutoni) - pierzchli przestraszeni ${ }^{34}$.

Ostatnim fragmentem analizowanego dzieła, który powinien nas zainteresować, jest wzmianka o tym, jak to do cesarza Fryderyka dochodziły różne niepokojące wieści z różnych stron. Jedna z nich, bardzo lakonicznie przedstawiona, przyszła z Polski (Polunia), a dotyczyła waśni, które wybuchły tam (w 1146 r., która to data jednak w tekście nie pada) pomiędzy piastowskimi braćmi ${ }^{35}$. Autor nie komentuje jednak w żaden sposób owej wiadomości. W pisanych później (a dokończonych przez Rahewina) Czynach Fryderyka powtórzył tę wzmiankęę ${ }^{36}$ zmienił jednak nazwę kraju na Polimia, znowu zresztą traktując tę ziemię jako prowincję imperium władanego przez Barbarossę.

Gesta Friderici zawierają więcej niż Kronika wiadomości o kraju Piastów. Szczególnie ciekawa jest dla nas relacja o interwencji cesarza w Polsce w celu restytucji władzy Władysława II (1157) ${ }^{37}$. Ta część dzieła napisana została już po śmierci Ottona z Fryzyngi przez Rahewina i jako jedyna z wszystkich przytaczanych wzmianek o Polsce posiada charakter zwartej, a przy tym dość rozbudowanej struktury. Być może stało się tak nie dlatego, że Rahewin wiedział o Polsce więcej niż Otto ${ }^{38}$,

s. 138 n.; J. P eters oh n, Prawnopaństwowy stosunek Pomorza Zachodniego do państw sąsiednich w okresie średniowiecza, w: Śląsk i Pomorze w historii stosunków polsko-niemieckich w średniowieczu, Poznań 1987, s. 103-123, tu s. 109 n.

${ }^{34}$ Ottonis Chronica, VII 21, s. 536. O kontekście zob. G. Varg a, Ungarn und das Reich vom 10. bis zum 13. Jahrhundert. Das Herrscherhaus der Árpáden zwischen Anlehnung und Emanzipation, München 2003, s. 163 n.

35 Ottonis Chronica, VII 34, s. 558.

${ }^{36}$ Gesta Friderici, I 31, s. 188.

37 Tamże, III 1, s. 398; o sprawie oceny kraju i ludzi ogólnie zob. H.-P. A p e 1 t, 'Gesta Friderici I. imperatoris’. Ein Beitrag zur Geschichtsschreibung des 12. Jahrhunderts, München 1971, s. 32-34.

${ }^{38}$ Podobną w charakterze strukturę narracyjną zbudował też Otto w napisanej jeszcze przez siebie części Czynów Fryderyka, gdy przedstawić chciał czytelnikowi Węgry (zob. niżej, przyp. 77). W obu przypadkach zastosowano typowy dla scholastyki sposób opisu, polegający na ulokowaniu opisywanego obiektu (kraju) w przestrzeni, ogólnym scharakteryzowaniu go, a następnie wyszczególnieniu typowych cech. 
ale dlatego, że rozwinięcia sprawy wymagał charakter dzieła i znaczenie owego fragmentu. Księga miała wszak opiewać dokonania Fryderyka, autor zatem chciał podnieść znaczenie tej wyprawy. Cały passus ma więc charakter odrębnej opowieści, rozpoczynającej się opisem położenia krainy, do której zmierzał szukający sławy i dążący do wymierzania sprawiedliwości monarcha ${ }^{39}$. Zdaniem Rahewina chociaż Polskę (Polimia) zamieszkują teraz Słowianie, to wedle opisów geografów kraj ten leży na skraju górnej Germanii ${ }^{40}$. Nasz autor podkreśla, że granice ziem piastowskich są obronne ${ }^{41}$, a wyznacza je na zachodzie Odra (Oddera), na wschodzie - Wisła (Iustula), na północy - Ruś i Morze Scytyjskie (jak określał Bałtyk ${ }^{42}$ ), na południu zaś - lasy czeskie. Ludność tej ziemi (Polani), za sprawą przyrodzonej dzikości owej krainy i sąsiedztwa ludów jeszcze bardziej odległych od cywilizacji, miała się stać, tak jak „rdzewieje żelazo od zardzewiałego żelaza”, zupełnie barbarzyńska (plene barbara) i bardzo wojownicza ${ }^{43}$. Na północy, nad morzem, zdaniem Rahewina, ludzie podczas głodu pożerali się wzajemnie, a miało być tam tak zimno, że nie dało się uprawiać ziemi - tak więc tamtejsi mieszkańcy żyli albo z polowania, albo z mordu. Wszyscy byli zatem piratami i napadali na „wyspy oceanu” (insula oceani) oraz Irlandię, Brytanię, Danię - chociaż tak daleko od tych ziem mieszkali. To właśnie ową nieokiełznaną dzikością Rahewin tłumaczy bunt dwóch braci (o imionach Bolizlaus oraz Gazimerus - nie znał widocznie Mieszka i Henryka) przeciwko Władysławowi (Lolizlaus), mężowi Gertrudy, wnuczki cesarza i córki margrabiego austriackiego Leopolda. Dalej nasz autor relacjonuje, że Władysław po wygnaniu z kraju zjawił się przed Konradem (1146) i został przez niego przychylnie wysłuchany.

Rahewin nie wiedział lub nie chciał pisać o nieudanej wyprawie Konrada z 1146 r., która prawdopodobnie z powodu wezbrania Odry oraz niechęci arystokracji saskiej zatrzymała się u granic Polski ${ }^{44}$. Zauważył jedynie, że Konrad wysyłał poselstwo do książąt piastowskich z żądaniem, by przywrócili oni najstarszego z braci do poprzedniej godności. Rozkaz został jednak zignorowany, co nie spotkało się z żadną reakcją Konrada ${ }^{45}$, który zresztą wkrótce zmarł. Sytuacja zmieniła się dopiero wtedy,

39 S. B a g g e, Ideas and narratives, s. 350-351.

${ }^{40}$ O takim sposobie ujmowania Europy Środkowej zob. B. K ü r b i s, Kształtowanie się pojęć geograficznych o Słowiańszczyźnie w polskich kronikach przeddługoszowych, Slavia Antiqua 4, 1953, s. 252-282; A. F. Grab s k i, Polska w opiniach obcych X-XIII wieku, Warszawa 1964, s. 85 n.

${ }^{41}$ Motyw naturalnej obronności kraju podkreślony został również w liście Fryderyka Barbarossy do Wibalda ze Stablo z 1157 r. (zob. przyp. 48), który Rahewin niewątpliwie znał.

${ }^{42}$ Nie tylko zresztą on, zob. K. Maleczyńs ki, „Sarmatae” i „Scytae” w pismach Gerberta z Aurillac, w: Europa - Słowiańszczyzna - Polska. Studia ku uczczeniu Profesora Kazimierza Tymienieckiego, Poznań 1970, s. 59-69.

${ }^{43}$ Gesta Friderici, III 1, s. 398; pokazany tam motyw wojowniczości (i inne jeszcze cechy) wiąże się z archetypem tzw. barbarzyńskiej północy, zob. D. F r a e s d o r ff, Der barbarische Norden. Vorstellungen und Fremdheitskategorien bei Rimbert, Thietmar von Merseburg, Adam von Bremen und Helmold von Bosau, Berlin 2005; M. K e 11 e r, Konturen. Die Darstellung der Ostslawen in Chroniken und Annalen des 9.-13. Jahrhunderts, w: Russen und Rußland aus deutsche Sicht 9.-17. Jahrhundert, München 1985, s. 57-83, tu s. 76 n.

44 J. H a u ziń s k i, Polska a Królestwo, s. 142.

${ }^{45}$ Gesta Friderici, III 2, s. 400: rex spretus est. O kontekście zob. M. B i n i a ś - S z k o p e k, Bolesław IV Kędzierzawy, książę Mazowsza i princeps, Poznań 2009, s. 235 n. 
gdy rządy w Rzeszy objął Fryderyk Barbarossa. I tym razem jednak - jak zaznacza autor - niesforni książęta myśleli początkowo, że będzie tak, jak za jego poprzednika, i nic sobie nie robili z zagrożenia, jakie zawisło nad nimi w związku ze złamaniem zasad sprawiedliwości, których gwarantem był monarcha Rzeszy ${ }^{46}$. Fryderyk nie mógł ścierpieć sytuacji ubliżającej jego majestatowi, której niestosowność powiększał fakt, że buntownicy zapomnieli o obowiązującej przysiędze posłuszeństwa i nie dostarczali mu należnego trybutu w wysokości 500 grzywien rocznie ${ }^{47}$. Być może passus ten oddaje w jakiś sposób treść rozmów Fryderyka I z polskimi posłami, którzy zjawili się w Halle na początku sierpnia 1157 r., ale ich postulaty zostały odrzucone ${ }^{48}$. Stylizowany przez Rahewina na władcę idealnego Barbarossa dobrze przygotował się do czekającego go przedsięwzięcia. Poprzednik ledwo doszedł do Odry, przedzierając się przez gęste lasy, ale dzielny Fryderyk z impetem przekroczył tę rzekę. Chociaż więc Polacy zgromadzili duże wojsko, wspomagane ponadto przez Rusinów (Rutheni), Partów (Parthi) ${ }^{49}$, Prusów (Prusci) i Pomorzan (Pomerani), armia ta przestraszyła się Fryderyka i uciekła znad Odry, paląc po drodze Głogów (Glogowa) i Bytom (Bitum), by grody te nie stały się punktem oparcia dla nacierających. Cesarz postępował za uchodzącymi, przeszedł przez obszar biskupstwa wrocławskiego (Frodezlau), a następnie wkroczył do poznańskiego (Poznan/Boznan). Fraza kronikarza zdradza, że towarzyszący Barbarossie duchowni znali przebieg granic polskich diecezji albo sądzili, że znają, i uznali przekaz tej wiedzy za zasadny.

Rahewin donosił też, iż książę Bolesław (Kędzierzawy), widząc potęgę wojsk Fryderyka, szukał kontaktu z niemieckimi hrabiami i książętami, aby za ich pośrednictwem dotrzeć do rozsierdzonego władcy i przekonać go do swoich racji ${ }^{50}$. Gdy to mu się udało, obiecywał Fryderykowi powrót pod „rzymską zwierzchność”, aby odzyskać jego łaskę, „nie chciał jednak podlegać panom niższej rangi, a tylko temu, w którego ręku była władza nad Imperium Rzymskim" ${ }^{51}$. Zauważmy tę różnicę. W oryginalnych tekstach Ottona (zarówno w Kronice, jak i w napisanych przez niego partiach Czynów Fryderyka) wymienia się regnum jako poziom w hierarchii władzy

${ }^{46}$ Gesta Friderici, s. 400. Dla Ottona panowanie Konrada III nie było raczej chwalebne, a pisał o nim z pewną niechęcią (J. J a k u b o w s k a, Koncepcja, s. 49 n.).

47 Gesta Friderici, III 2, s. 400.

${ }^{48}$ List Fryderyka do Wibalda ze Stablo (Codex diplomaticus nec non epistolaris Silesiae, t. I, wyd. K. Maleczyński, Wrocław 1956, nr 39; nowa edycja: Das Briefbuch Abt Wibalds von Stablo und Corvey, wyd. M. Hartmann. Monumenta Germaniae historica, Briefe der deutschen Kaiserzeit, t. IX, Hannover 2012, nr 451); o relacji tej zob. Ch. U e b a c h, Die Ratgeber Friedrich Barbarossas (1152-1167), Marburg 2008, s. 54 n.

49 Nie wiadomo, jaki lud Rahewin miał w tym wypadku na myśli. Być może to jego wiedza o geografii starożytnej (i łączenie imperium Fryderyka ze dawnym Rzymem) sprawiła, że Partów (znanych przeciwników Rzymian) umieścił on tu jako mieszkańców Wschodu.

${ }_{50}$ Wincenty z Pragi donosił o głównej roli księcia czeskiego w osiągnięciu układu (zob. przyp. 55).

${ }_{51}$ Gesta Friderici, III 4, s. 402: [Bolesław] promissionibus, ut sub ingum Romanae ditionis et in gratiam principis recipi mereretur, postulavit - - debere autem dedignari dominos humiliores, non eum, cuius in potestate sit Romanum imperium. Otto z Fryzyngi (a także wielu ówczesnych intelektualistów Rzeszy) kojarzył współczesne mu Imperium Romanum, państwo Fryderyka, z antycznym imperium cezarów (J. J a k u b o w s k a, Koncepcja, s. 44 n.; G. L a b u d a, O stosunkach, s. 52 n.). 
Imperii Christani, który przyjmować ma zwierzchność nad krajem Piastów. Tu zaś - być może oddając rzeczywiste postulaty strony polskiej ${ }^{52}$ - wyraźnie napisano o podległości Polski jedynie Cesarstwu Rzymskiemu.

Łaskawy Fryderyk hołdował hasłu ,zwyciężonych szanować, dumnych upokarzać” i ,nie chciał danego mu przez Boga zwycięstwa nurzać we krwi”, przyjął zatem prośby Bolesława i ten w pobliżu Krzyszkowa (Crisgowe) (53 $^{53}$ upadł mu do nóg, a dzięki poręce książąt Rzeszy został przywrócony do łaski ${ }^{54}$. Brak w tym opisie szczegółów owego wydarzenia, które - pewnie ubarwiając w niekorzystny dla Bolesława Kędzierzawego sposób - przedstawił czeski kronikarz Wincenty z Pragi, pisząc o zjawieniu się władcy polskiego przed Barbarossą w pozie pokutnej, boso, z obnażonym mieczem nad głową ${ }^{55}$. Doszło do ugody. Rahewin najpierw napisał o przysiędze, złożonej przez księcia w imieniu swoim i wszystkich Polaków (Polani), według której wygnanie z kraju księcia Władysława „nie dokonało się na hańbę imperium" (ignominiam Romani Imperii) ${ }^{56}$. Następnie książę miał obiecywać, że przekaże cesarzowi 2000 grzywien (srebra?), zaś 1000 jego książętom, ponadto dla cesarzowej miało być przeznaczonych 20 grzywien złota, a dla dworu - 200 grzywien srebra. Te ostatnie daniny, jak zaznacza kronikarz, miały jakoby zostać na Bolesława nałożone z powodu jego opieszałości w uiszczaniu należnego trybutu oraz dlatego, że nie zjawiał się na zjazdach Rzeszy ani nie złożył stosownej przysięgi wierności. Książę miał też ponadto obiecać swój udział w szykowanej wyprawie Barbarossy do Italii oraz że pojawi się w Magdeburgu na najbliższe Boże Narodzenie, by poddać się osądowi panów Rzeszy z powodu skargi wypędzonego z kraju najstarszego brata. Potem, jak to było w zwyczaju, Bolesław Kędzierzawy miał złożyć przysięgę wierności i oddać swego brata Kazimierza oraz pewnych swoich możnych jako zakładników złożonych obietnic ${ }^{57}$. Rahewin napisał następnie, że cesarz, odniósłszy „wspaniałe zwycięstwo, prowadzony przez Boga”, powrócił do Niemiec, ale gdy po czterech miesiącach od opisanego hołdu zawitał do Magdeburga, nie zastał tam Bolesława, który według kronikarza nigdy nie zamierzał wypełnić zobowiązań. Przybyli jedynie jacyś nieupoważnieni do udziału w mającym odbyć się sądzie posłowie

${ }^{52}$ Zob. Galli Anonimi Cronicae et gesta ducum sive principum Polonorum, III 2, wyd. K. Maleczyński, Monumenta Poloniae historica, series nova, t. II, Kraków 1952, s. 130, gdzie kronikarz napisał o gotowości podporządkowania się Bolesława Krzywoustego „Kościołowi rzymskiemu" i jego brak zgody na płacenie trybutu królowi niemieckiemu.

${ }^{53}$ Gesta Friderici, III 5, s. 402.

${ }^{54}$ Autor zarysowuje tu schemat aktu określanego jako deditio - zob. G. A 1 th o ff, Zur Bedeutung symbolischer Komunikation für das Verständnis des Mittelalters, Frühmittelalterliche Studien 31, 1997, s. 370-389, tu s. 382; Z. D a le w s k i, Między Krzyszkowem a Mediolanem, w: Kościół, kultura, społeczeństwo. Studia z dziejów średniowiecza i czasów nowożytnych, Warszawa 2000, s. 131-141.

${ }_{55}$ Letopis Vincenciův, wyd. J. Emler, Fontes rerum Bohemicarum, t. II, Praha 1874, s. $424 \mathrm{n}$.

${ }^{56}$ Warto zwrócić uwagę na tę frazę, odwołującą się do dyskutowanej obecnie intensywnie w nauce kwestii roli ,honoru” w polityce Fryderyka Barbarossy - zob. K. G ö r i c h, Die Ehre Friedrich Barbarossas. Kommunikation, Konflikt und politisches Handeln im 12. Jahrhundert, Darmstadt 2001, zwł. s. 358 (o epizodzie polskim dość lakonicznie).

${ }^{57} \mathrm{O}$ losach zakładników, których bynajmniej, pomimo ,wiarołomstwa” Bolesława Kędzierzawego, nie ukarano, zob. M. B i n i a ś - S z k o p e k, Bolesław, s. 170-171. 
księcia, który wymówił się też od udziału w wyprawie do Włoch ${ }^{58}$. Warto zauważyć, że nasz autor nie rozwodził się szerzej nad tą sprawą (nie wiadomo np., co stało się z zakładnikami), zauważył ją, ale szybko przeszedł do opisywania dalszych działań Fryderyka. Z jednej strony nie miał tu materiału do snucia swej opowieści - cesarz przecież nie angażował się już bezpośrednio w konflikt w łonie dynastii piastowskiej, z drugiej jednak ten brak jakiegokolwiek komentarza jest dość wymowny. Wydaje się, iż po prostu kraj o marginalnym dla cesarstwa znaczeniu zjawił się na kartach dzieła jedynie po to, by umożliwić objawienie się dobrych chęci Barbarossy rozszerzania ładu i sprawiedliwości (a więc cywilizacji) na obszary ich pozbawione. Cytowana relacja jest jedynym u Rahewina obszerniejszym miejscem dotyczącym bezpośrednio kraju Piastów.

W Czynach Fryderyka znajdziemy jeszcze tylko jedną wiadomość wiążącą się jakoś z Polską. Mianowicie Rahewin w obszernym ustępie, żałując śmierci swojego przełożonego, biskupa Ottona, napisał o jego powiązaniach genealogicznych. Po wymienieniu tych najwyższych, z monarchami i arystokracją niemiecką, wspomniał też, że miał on wspólnych rodziców z Gertrudą księżną czeską, Bertą „księżną Polaków" (ducissa Polanorum) oraz niejaką Itą margrabianką Montferrat, która miała zostać matką cesarzowej Hiszpanii ${ }^{59}$. W istocie Berta, jedna z sióstr Ottona, wyszła za Henryka von Bogen, burgrabiego Ratyzbony, natomiast księżną polską została inna z sióstr - Agnieszka, której imienia kronikarz nie znał. To córką jej i Władysława II Wygnańca była Ryksa (Richilda, Rica), która w 1152 r. wyszła za Alfonsa VII kastylijskiego $^{60}$. Znamienne, że autor, człowiek tak bliski Ottonowi z Fryzyngi, nie pamiętał o jego siostrze i słabo kojarzył jego siostrzenicę.

Jeśli porównamy wzmianki o Polsce napisane przez Ottona z Fryzyngi z tymi, których autorem był Rahewin, to cechą wspólną wszystkich będzie skromna ich liczba i ubóstwo informacyjne - w zestawieniu oczywiście z wiadomościami dotyczącymi Niemiec i innych obszarów Europy Zachodniej. Różni natomiast obu autorów charakter ich doniesień o Polsce. Biskup Fryzyngi pisał niezwykle lakonicznie, nawet o buncie braci przeciwko swojemu szwagrowi informował więcej niż skromnie. Rahewin natomiast zbudował sporą relację, ale nie jest ona w istocie poświęcona Polsce, ale wyprawie Fryderyka. Autor chciał po prostu przekazać czytelnikowi, jak dzielnym władcą był Barbarossa, który udał się do tak odległego, dzikiego kraju i z sukcesem prowadził tam wojnę, starając się nadaremno zaprowadzić porządek wśród barbarzyńców na krańcach świata. Wydaje się, że podobnie wyprawę cesarską opisałby i sam Otto, gdyby dostał od losu taką szansę. Odmiennie od swego mentora, który stale widział zależność Polski od Królestwa Niemieckiego, Rahewin udokumentował, być może nawet bezwiednie, dążenia władców

${ }^{58}$ Gesta Friderici, III 5, s. 405.

59 Tamże, IV 14, s. 538.

${ }^{60}$ K. J a s i ńs ki, Rodowód Piastów śląskich, wyd. 2, Kraków 2007, s. 295-296; M. D e m bińs ka, A Polish princess - empress of Spain and countess of Provence in the $12^{\text {th }}$ century, w: Frauen in Spätantike und Frühmittelalter. Lebensbedingungen, Lebensnormen, Lebensformen, wyd. W. Affeldt, Sigmaringen 1990, s. 283-290; K. M a l e c z y ń s k i, Dzieje Ryksy córki Władysława Wygnańca śląskiego, cesarzowej Hiszpanii i hrabiny Prowansji, Lwów 1933, s. 237-307. 
polskich (najwyraźniej jakoś zaakceptowane przez Barbarossę), by podlegać jedynie cesarzom rzymskim ${ }^{61}$.

W obu dziełach Ottona (i w kontynuacji Rahewina) Polska zajmowała jednak w pewnej dającej się tam zauważyć hierarchii władztw Europy Środkowej - miejsce najniższe ${ }^{62}$. Wynikało to nie tylko $\mathrm{z}$ rangi królewskiej, jaką posiadali w tym czasie władcy Czech i Węgier, ale też i z pewnej obcości kraju oraz jego mieszkańców, wynikającej chociażby ze słabych kontaktów z nimi. Polacy nie zjawiali się na ogół na zjazdach Rzeszy (w odróżnieniu od Czechów, utrzymujących stały związek polityczny z Niemcami) ani w szeregach wojsk posiłkowych jej monarchów ${ }^{63}$. Większa wiedza o Węgrzech wynikała natomiast chociażby z dogodniejszego położenia tego kraju na drodze do Bizancjum i Ziemi Świętej. Swoje znaczenie miała też na pewno ówczesna potęga państwa Arpadów i ich aktywność w wielkiej polityce.

Najwięcej wzmianek w obu dziełach poświęcono Czechom. Ich władcy też, zwłaszcza w Czynach Fryderyka, ukazani zostali w o wiele lepszym świetle niż inni dynaści środkowej Europy ${ }^{64}$. Jednak i w odniesieniu do nich zdarzało się, że Otto stosował określenia „barbarzyńcy”. Chociaż sformułowanie to użyte wprost pojawia się rzadko, to spotkamy je w komentarzu do relacji o plądrowaniu przez Czechów okolic Norymbergi w 1127 r. ${ }^{65}$, gdy książę Sobiesław I (w tekście występujący pod pomylonym imieniem Ulryka/Udalryka) wspierał armię króla niemieckiego przeciw zbrojnej opozycji. Innym razem czescy „barbarzyńcy” zaatakowali zmierzającą do ich kraju wyprawę Lotara z Supplinburga i rozbili ją w słynnej bitwie pod Chlumcem 1126 r. (znamienne dla plotkarskiego nieco stylu kronikarza jest to, że najpierw pisał on o Norymberdze, później o Chlumcu) ${ }^{66}$, lecz oczywiście ich książę (Sobiesław, znów pomylony z Udalrykiem) ostatecznie padł do stóp władcy Rzeszy (nazywanego raz królem, raz cesarzem) i prosił o wybaczenie, a potem złożył hołd i przysięgę wierności. Akt ów rozwiązał konflikt, jeśli chodzi o monarchę, ale sami Sasi mieli z powodu doznanych wówczas wielkich strat w ludziach żywić od tej pory wielką nienawiść do Czechów ${ }^{67}$.

Chociaż w oczach Ottona kraj, jak już wspomniano, nie wchodził w skład imperium Karola Wielkiego i w klasyfikacji stworzonej przez kronikarza nie znalazł się w lepszej, karolińskiej części Europy, to jednak w pewien sposób się o nią otarł. Przy opisywaniu bowiem podziału imperium frankijskiego, który kronikarz umieścił pod

${ }^{61}$ Zob. G. L a bu da, O stosunkach, s. 50.

${ }^{62} \mathrm{~Np}$. gdy Rahewin opisywał poselstwa cesarskie, donoszące o synodzie rzymskim, jako jedyni władcy Europy Środkowej wspomniani zostali królowie Czech i Węgier (Gesta Friderici, IV 40, 84, s. 695, 705).

${ }_{63}$ Zob. np. tamże, III 29, s. 454.

${ }^{64}$ Szkicowy przegląd nastawienia kronikarzy niemieckich do Czech dał N. K e r s k e n, Das přemyslidische Böhmen in der zeitgenössischen Historiographie des Reichs, w: Böhmen und seine Nachbarn in der Přemyslidenzeit im mitteleuropäischen Vergleich, Ostfildern 2011 (Vorträge und Forschungen 74), s. 385-436.

${ }_{65}$ Gesta Friderici, I 17, s. 158.

${ }^{66}$ Tamże, I 21, s. 164 n.

${ }^{67}$ Tamże, I 22, s. 166. W istocie rywalizacja pomiędzy Czechami a Sasami istniała już od X w. (F. Gr a u s, Böhmen zwischen Bayern und Sachsen. Zur böhmischen Kirchengeschichte des 10. Jahrhunderts, Historica 17, 1969, s. 5-42). 
876 r., zaznaczył on, że Czechy i Morawy miały się znaleźć pod władzą Karlomana (syna Ludwika Niemieckiego) wraz z Bawarią, Panonią i Karyntią ${ }^{68}$. Od tej pory Czechy w narracji Ottona stale już występują bez żadnych wahań jako prowincja podlegająca władzy monarchów Rzeszy - nie wiadomo jednak, czy w zależności od królestwa, czy od cesarstwa, gdyż kronikarz ani jego kontynuator nigdy tego nie precyzują. Dzieje związków tego kraju z imperium podawane są wyrywkowo i przy okazji opisywania dokonań władców wschodniofrankijskich, a następnie niemieckich. Otto wie zatem, że Arnulf z Karyntii powierzył księstwo (ducatum) „królowi” Morawian Świętopełkowi, a swojego jedynego syna kazał ochrzcić tym imieniem (Zwentibold ${ }^{69}$. Zauważa później, że po koronacji w 936 r. król Otto I pokonał Słowian, którzy „nazywają się także Czechami”70, a Henryk III na początku swojego panowania (w 1040 r.) nieostrożnie wszedł do zbuntowanych Czech i doznał tam „W lesie” ciężkich strat, ale później pokonał ostatecznie ich księcia (chodzi o nienazwanego tu z imienia Brzetysława) $)^{71}$.

Warto podkreślić, że dla Ottona z Fryzyngi i Rahewina prawdziwie uprawionymi do rządów nad Czechami byli jedynie ci spośród tamtejszych władców, którzy współpracowali z monarchą Rzeszy. Stwierdzenie to sprawdza się zwłaszcza w przypadku Władysława II, zajmującego w obu dziełach miejsce szczególne. Żaden mianowicie inny nie-niemiecki władca nie skupił na sobie tyle ich uwagi. Zadecydowała o tym oczywiście stała, długoletnia współpraca księcia, a później króla czeskiego z Fryderykiem Barbarossą, ale być może miał też swoje znaczenia fakt, iż Władysław był przecież szwagrem Ottona z Fryzyngi. W tym jednak przypadku moc tego przypuszczenia osłabia nasza wiedza na temat potraktowania przez kronikarza polskiego szwagra, Władysława Wygnańca, któremu w Historii dwóch państw kronikarz poświęcił bardzo mało miejsca. Sposób prezentacji czeskiego Władysława II przez Ottona z Fryzyngi i Rahewina jest tematem osobnym, który zresztą był już podejmowany $^{72}$. Tu warto jedynie zaznaczyć, że władca ten jako jedyny z kręgu dynastów środkowoeuropejskich wychodził z cienia owego gorszego świata, jaki wykreowany został w analizowanych przez nas tekstach. Władysław dzięki koneksjom rodzinnym i przebywaniu z lepszymi - odwracając tu przytoczoną przez Rahewina w odniesieniu do Polaków metaforę o zardzewiałym żelazie - stał się szlachetnym, dzielnym władcą chrześcijańskim, któremu sam cesarz oddał należne honory, przekazując mu tytuł i koronę królewską ${ }^{73}$. Warto zauważyć, że chociaż Otto wiedział

${ }^{68}$ Ottonis Chronica, VI 5, s. 442.

69 Tamże, VI 11, s. 448.

70 Tamże, VI 19, s. 460.

71 Tamże, VI 32, s. 480.

72 J. S o b i e s i a k, Od Lechowego Pola (955) do Mediolanu (1158). W służbie monarchów Rzeszy. Relacje czeskich źródeł narracyjnych o wyprawach Przemyślidów, Lublin 2011, s. $91 \mathrm{n}$. W Niemczech temat ten jest raczej pomijany - W. G e o r g i, Friedrich Barbarossa und die auswärtigen Mächte. Studien zur Außenpolitik 1159-1180, Frankfurt am Main 1990, o Władysławie II czeskim napisał zdawkowo (nie ma zaś tam w ogóle słowa o Polsce).

${ }^{73}$ Gesta Friderici, III 16, s. 426-428; wzmianki o wojnie domowej w Czechach i wypędzeniu Władysława II w 1140 r.: Ottonis Chronica, VII 26, s. 544 n.; o małżeństwie z córką Leopolda, Gertrudą: tamże, VII 34, s. 558. Tego rodzaju nastawienie do Czechów było w Niemczech szersze; Bartłomiej Anglik (De proprietatibus rerum) pisał w Magdeburgu ok. 1230 r., 
o związkach swojej rodziny z Przemyślidami oraz jej (a także monarchów Rzeszy) sojuszach $\mathrm{z}$ władcami czeskimi ${ }^{74}$ - wspominał o nich np. przy opisywaniu wojny domowej w Rzeszy w 1105 r., w której jego ojciec oraz czeski Borzywój II razem wspierali Henryka IV ${ }^{75}$ - to jednak Rahewin w swojej części Czynów Fryderyka, proporcjonalnie do wielkości tekstu, napisał o Władysławie II więcej i miał do niego jakby cieplejszy stosunek ${ }^{76}$.

Jeśli chodzi o nastawienie Ottona z Fryzyngi do Węgier, to trzeba przyznać, iż miało ono dość specyficzny charakter. $Z$ jednej strony kronikarz nie ukrywał, że nie lubił mieszkańców państwa Arpadów, ani też samych władców tego kraju, z drugiej jednak strony poświęcił mu dość duży, osobny akapit w swoich Czynach Fryderyka. Być może spore zainteresowanie Węgrami wynikało z faktu, że biskup Otto brał u boku swojego królewskiego brata, Konrada III, udział w II wyprawie krzyżowej, której droga wiodła właśnie przez Węgry ${ }^{77}$. Podobnie jak w przypadku Polski zrobił to później Rahewin, biskup Fryzyngi położenie Węgier stosunkowo dokładnie opisał, wymienieniając ziemie z nimi sąsiadujące ${ }^{78}$. Zgodnie z częstą opinią owego czasu uważał, że kraj ten zewsząd otoczony był górami i lasami, w środku zaś był równinny. Przypisuje owej ziemi niezwykłą żyzność, a klimatowi łagodność, przyrównując ją do raju. Kronikarz skontrastował jednak tę uwagę - zgodnie z zasadami archetypu „barbarzyńskiej Północy”79 - wiadomością, iż sami Węgrzy nie zasługują w żaden sposób, by władać tak wspaniałą ziemią. Ze względu na to, że są to ludzie niecywilizowani (gens barbarica), niewiele mają (murowanych) umocnień i budowli. Dowodzenie, dlaczego sytuacja tam tak wygląda, podobne jest w stylu do wspomnianej już wyżej charakterystyki Polaków: kraj Węgrów sąsiaduje z prymitywnymi ludami, które nań napadają - dlatego i sami Węgrzy mają być nieokrzesani w mowie i obyczajach. Także ich wygląd raził Ottona: mieli być oni tak mali i brzydcy, że nawet trudno ich nazwać ludźmi; kronikarz dziwił się boskiej wyrozumiałości, która tak piękny kraj oddała takim szkaradom. Również charakter Węgrów miał być zły. W przebiegłości równi mieli być Grekom, co stanowiło w ówczesnej historiografii

że większość Słowiańszczyzny zamieszkuje gens inculta, mniejszą zaś, tj. Czechy, lud pokojowy, co zawdzięcza wpływom niemieckim i przemieszaniu się z Niemcami (A. F. G r a b s k i, Polska, s. 97).

${ }^{74}$ Kronikarz podaje, że żona Borzywoja, Gerberga, była siostrą Leopolda, ojca Ottona (Ottonis Chronica, VII 9, s. 514), a także podkreśla, że jego ojciec był wspierany przez księcia czeskiego (VII 15, s. 526).

75 Tamże, VII 8-9, s. 512 n.

76 Podobnie zresztą i do Węgrów Rahewin odnosił się lepiej niż Otto, zob. H.-P. A p e 1 t, 'Gesta Friderici I imperatoris', s. 28 n.

77 Ottonis Chronica, I 45-48, s. 216-219; zob. też wstęp, tamże, s. XXXI; szerzej o niemieckim postrzeganiu Węgier pisał T. R a d e k, Das Ungarnbild in der deutschsprachigen Historiographie des Mittelalters, Frankfut am Main 2009, dając jednak raczej zestawienie doniesień niż właściwą analizę problemu.

${ }^{78}$ Gesta Friderici, I 33, s. 192 n.

79 Według niego obszary barbarzyńskie cechuje niezwykła żyzność ziemi i bujność przyrody, zob. wyżej, przyp. 43, a także np. H. K r a b b o, Eine Schilderung der Elbslawen aus dem Jahre 1108, w: Papsttum und Kaisertum. Forschungen zur politischen Geschichte und Geisteskultur des Mittelalters. Paul Kehr zum 65. Geburtstag dargebracht, München 1926, s. $250-262$. 
niemieckiej mocną przyganę ${ }^{80}$. Ich domy miały być liche, najczęściej słomiane, a w dodatku latem i jesienią pomieszkiwali w namiotach. Kronikarz oburzał się, pisząc o wielkiej (politycznej i gospodarczej), despotycznej władzy króla nad możnymi węgierskimi. Według niego wiece były tam tylko czczą formalnością, bo i tak nikt nie śmiał wyrażać na nich oficjalnie innego zdania, odmiennego niż te, które ujawniał monarcha; jeśli już się to zdarzało, oponent wtrącany bywał do więzienia bez żadnego wyroku. Oskarżony nie mógł się bronić, a wola króla była tam prawem ${ }^{81}$. Otto ganił u Węgrów i to, że do władcy należała przeważająca część dochodów kraju, a żaden pan nie mógł bić swojej własnej monety. Wszystko to odbiegało, co podkreśla kronikarz, od obyczajów jego ojczyzny. Węgrzy posiadali też według Ottona jedynie lichą broń i w ogóle mieli nędzną powierzchowność, w walce zaś tylko z pozoru mieli być dzielni ${ }^{82}$, a jeśli już się to zdarzało, to - zdaniem kronikarza - wynikało tylko z naśladowania sztuki wojennej Niemców, których równie pozytywny wpływ uwidaczniał się w imitowaniu ich ubioru i uzbrojenia.

Biskup Fryzyngi był dość dobrze zorientowany w historii pojawienia się Węgrów nad Dunajem. Najpierw zatem zauważył, że wyszli oni ze Scytii (którą zgodnie z geografią antyczną widział na terenie dzisiejszej Ukrainy), z której przepędzeni zostali przez Pieczyngów (Pezenati) i po wyparciu - jego zdaniem - Awarów, osiedli $\mathrm{w}$ Panonii ${ }^{83}$. Zgodnie $\mathrm{z}$ topiką określania ludów barbarzyńskich Otto twierdził, że Madziarzy w chwili pojawienia się w środkowej Europie mieli być tak dzicy i zwierzęcy, że jedli surowe mięso i pili nawet ludzką krew. Ich główną bronią, którą chętnie używali w pozorowanej ucieczce, były strzały. To nimi np. mieli wybić wojsko przeciwników, by następnie bez przeszkód złupić Lombardię w $901 \mathrm{r}^{84} \mathrm{~W}$ stwierdzeniu tym tkwi znaczna przygana. Łuk i strzały, jak pouczają przykłady różnych zachodnioeuropejskich tekstów z epoki, przez kształtujące się rycerstwo były uważane za broń poślednią, charakterystyczną dla gminu albo właśnie dzikusów (prawdziwy wojownik winien bowiem walczyć otwarcie, twarzą w twarz, posługując się mieczem) ${ }^{85}$.

Pisząc o historii kontaktów Węgrów z jego ojczyzną, Otto dość zwięźle donosił o łupiestwach dokonywanych przez nich w Niemczech ${ }^{86}$. Niewiele miał do powiedzenia o bitwie pod Riade, nie podał nawet jej daty $(933)^{87}$. Nieco więcej napisał dopiero o kampanii zakończonej zwycięstwem na Lechowym Polu, donosząc, jak to w 955 r. „najokrutniejszy lud Węgrów” (Ungarorum gens sevissima) w niezliczonej liczbie wpadł do Niemiec. Dziejopis zauważył dzielną postawę św. Udalryka, obrońcy Augsburga, i oczywiście samego króla Ottona, który pobił barbarzyńców

${ }^{80}$ Zob. np. Liutprandi Antapodosis, w: Liudprandi episcopi Cremonensis Opera omnia, J. Becker, Scriptores rerum Germanicarum, Hannover 1915, s. 8 n.

${ }^{81}$ Gesta Friderici, I 33, s. 194.

82 Otto trzymał się tej opinii, opisując np. udział Niemców w walkach wewnętrznych na Węgrzech, gdy to Borys syna Kolomana walczył w 1132 r. z Belą II Ślepym, po którego stronie zaangażowali się hrabiowie austriaccy (Ottonis Chronica, VII 21, s. 536 n.).

83 Tamże, VI 10, s. 448.

${ }^{84}$ Tamże, VI 14, s. 453.

${ }^{85}$ F.-R. E r k e n s, Militia und Ritterschaft. Reflexionen über die Entstehung des Rittertums, Historische Zeitschrift 258, 1994, s. 623-659.

86 Ottonis Chronica, VI 15, s. 454.

87 Tamże, VI 18, s. 460. 
tak, że ten „najdzikszy wśród ludów” (gens omnium inmanissima) nie śmiał już więcej najeżdżać „naszego królestwa, a tylko krył się za wałami i palisadami w bagnistych miejscach" $"$.

Odmiennie od Czech (których status traktowany był różnie), a zwłaszcza Polski, kraj Węgrów tytułowany jest $\mathrm{u}$ Ottona konsekwentnie mianem regnum, a nazwa ta w analizowanych tekstach wyraźnie oznacza samodzielny, niezależny obszar, jak np. Francja czy Anglia. Nie oznacza to oczywiście, że Otto czy Rahewin odmawiali władcy Rzeszy prawa ingerencji w wewnętrzne sprawy owego regnum ${ }^{89}$ czy też legitymizacji dążeń do podporządkowania go swej władzy ${ }^{90}$. Tego rodzaju działania były dla obu autorów zupełnie uzasadnione - wszak obowiązkiem imperatora jest zaprowadzanie ładu i sprawiedliwości na całym zanarchizowanym obszarze barbaricum. U naszych autorów wyraźnie ujawnia się jednak przekonanie o pewnej odrębności Węgier, co wydaje się wiązać właśnie z rangą królestwa, którą kraj ten już od dawna posiadał. Być może istotne dla uznania królestwa Arpadów było też zapisane przez Ottona mniemanie, iż nawrócenie „króla Stefana” i chrzest jego kraju dokonały się za sprawą siostry „najbardziej pobożnego cesarza” Henryka II, Gizeli, sam zaś Stefan został świętym ${ }^{91}$. Dość dobrą znajomość realiów węgierskich przez obu analizowanych tu autorów poświadcza fakt używania przez nich imion władców węgierskich (niemal zawsze w poprawnej formie) oraz imion ich synów, walczących pomiędzy sobą o władzę, zamiast - tak jak np. w przypadku Polski - pisania jedynie ogólnie o panach kraju lub jego książętach.

Zupełnie marginalnie w rozważanych tekstach potraktowane zostały ziemie ruskie. W Czynach Fryderyka Rusowie pojawiają się tylko okazjonalnie, jako wojska posiłkujące władców polskich, bez podawania jakichkolwiek szczegółów. Nazwa ich kraju występuje przy opisywaniu wschodniej granicy lepiej znanych autorom państw polskiego i węgierskiego. W Kronice wspomniano nieco więcej o Rusi z racji relacjonowania interwencji Konrada III u cesarzy bizantyjskich Jana i Manuela (1142-1145). Król skarżył się na obrabowanie i zabicie przez Rusów (Ruthenen) - nie wiadomo, gdzie - niemieckich podróżnych (prawdopodobnie kupców) i zabranie im złota ${ }^{92}$. Otto nie napisał jednak o skutku tych działań. Co ciekawe, biskup Fryzyngi, donoszący przecież o różnych faktach z dziejów monarchów Rzeszy, nie napisał nic o wielkim skandalu, jaki zdarzył się z udziałem księżniczki ruskiej zaledwie pół wieku wcześniej. Chodzi mianowicie o sprawę Adelajdy-Eupraksji ${ }^{93}$, żony Henryka IV, która uciekła od męża i oskarżała go przed papieżem oraz wrogimi mu biskupami włoskimi na synodzie w Piacenzy w 1095 r. o dewiację i wszetecznictwo graniczące z herezją.

${ }_{88}$ Tamże, VI 20, s. 462.

89 Tamże, VI 32, s. 480 (pod 1040 r. [recte: 1044] o interwencji Henryka III w sprawie Piotra [Orseolo], wypartego przez Albę [Samuela Abę]), V 33, VII 13, s. 486, 520 (nieudane wyprawy przeciwko Andrzejowi I i Kolomanowi).

${ }^{90}$ Szerzej o ówczesnej sytuacji: G. Va rg a, Ungarn, s. 186 n.; N. B e r e n d, P. W i s z e w ski, P. Urbań czyk, Central Europe in the High Middle Ages, Bohemia, Hungary and Poland c. 900 - c.1300, Cambridge 2013, s. 221 n.

91 Ottonis Chronica, VI 27, s. 472.

${ }_{92}$ M. Ke 11 e r, Konturen, s. 78.

${ }^{93}$ G. A 1 t h off, Heinrich IV., Darmstadt 2006, s. 207 n.; H. R ü B, Eupraxia-Adelheid. Eine biographische Annäherung, Jahrbücher für Geschichte Osteuropas 54, 2006, s. 481-518. 
Sprawa była powszechnie znana, donosiły bowiem o niej stosunkowo szeroko inne niemieckie kroniki (Frutolfa z Michelsbergu, Bernolda z Konstancji) ${ }^{94}$.

W podsumowaniu niniejszych rozważań można stwierdzić, że zarówno dla Ottona z Fryzyngi, jak też i dla Rahewina cały region Europy Środkowej okazywał się obszarem należącym wprawdzie do cywilizacji chrześcijańskiej, ale dość ułomnym kulturowo - ziemie te w mniemaniu naszych autorów powinny podlegać zwierzchnictwu władców Rzeszy, którzy z natury rzeczy mieli tam prawo, a nawet obowiązek, zaprowadzać porządek i ład moralny, stale łamany przez zanarchizowanych tubylców. Czechy w obu dziełach znajdowały się (mniej lub bardziej, w zależności od kontekstu opisywanej sytuacji) już niemal w obrębie lepszego świata, który podlegał monarchom Rzeszy. Władcy Czech byli partnerami dla królów niemieckich i ich arystokracji. Węgry oceniane były nieco gorzej, choć postrzegane jako odrębne od Rzeszy królestwo. Jeśli jednak Otto z Fryzyngi zachowywał w stosunku do nich dość dużą rezerwę, to już Rahewin żywił wobec nich cieplejsze uczucia. Najdalej, w sensie kulturowym, spośród wschodnich sąsiadów Niemiec, które w mniemaniu obu naszych autorów stanowiły centrum świata, leżała Polska. Obaj kronikarze najmniej o niej wiedzieli, przekręcali jej nazwę oraz różnie określali jej mieszkańców, mylili imiona władców (o ile zresztą w ogóle ich używali). W przypadku Polski też, wymykającej się zwierzchniej władzy monarchów Rzeszy, istniała kontrowersja, czy ma ona podlegać Regnum Teutonicum (jak uważał Otto z Fryzyngi), czy raczej Imperium Romanum (jak napomknął Rahewin).

\section{BIBLIOGRAFIA}

Althoff G., Heinrich IV., Darmstadt 2006.

Althoff G., Zur Bedeutung symbolischer Komunikation für das Verständnis des Mittelalters, Frühmittelalterliche Studien 31, 1997.

Annales Magdeburgenses, wyd. G. H. Pertz, Monumenta Germaniae historica, Scriptores, t. XVI, Hannover 1859.

Apelt H.-P., 'Gesta Friderici I imperatoris'. Ein Beitrag zur Geschichtsschreibung des 12. Jahrhunderts, München 1971.

Bagge S., German historiography and the twelfth-century renaissance, w: Representations of Power in Medieval Germany, 800-1500, Turnhout 2006 (International Medieval Research 16).

Bagge S., Ideas and narratives in Otto of Freising's 'Gesta Frederici', Journal of Medieval History 22, 1996.

Berend N., Wiszewski P., Urbańczyk P., Central Europe in the High Middle Ages, Bohemia, Hungary and Poland c. $900-$ c.1300, Cambridge 2013.

Biniaś-Szkopek M., Bolesław IV Kędzierzawy, książę Mazowsza i princeps, Poznań 2009.

Buschinger D., Deutsch-polnische Wechselbeziehungen im Mittelalter, w: Deutsche Polenliteratur, Wrocław 1991 (Acta Universitatis Wratislaviensis nr 1297, Germanica Wratislaviensia 42).

Classen A., Mauritius von Craûn and Otto von Freising’s „The Two Cities”: 12th- and 13th-century scepticism about historical progress and the metaphor of the ship, The German Quarterly $79,2006, \mathrm{nr} 1$.

Codex diplomaticus nec non epistolaris Silesiae, t. I, wyd. K. Maleczyński, Wrocław 1956.

Dalewski Z., Kaiser Lothar III., Soběslav I. von Böhmen und Bolesław III. von Polen auf dem Hoftag in Merseburg im Jahre 1135, Zeitschrift für Ostmitteleuropa-Forschung 50, 2001.

${ }^{94}$ M. K e 11 e r, Konturen, s. 74 n. 
Dalewski Z., Między Krzyszkowem a Mediolanem, w: Kościół, kultura, społeczeństwo. Studia z dziejów średniowiecza i czasów nowożytnych, Warszawa 2000.

Das Briefbuch Abt Wibalds von Stablo und Corvey wyd. M. Hartmann. Monumenta Germaniae historica, Briefe der deutschen Kaiserzeit, t. IX, Hannover 2012.

Das Reichschronik des Annalista Saxo, wyd. K. Nass, Monumenta Germaniae Historica, Scriptores, t. XXXVII, Hannover 2006.

Das Rolandslied des Pfaffen Konrad, wyd. C. Wesle, P. Wapnewski, Tübingen 1985.

Dembińska M., A Polish princess - empress of Spain and countess of Provence in the $12^{\text {th }}$ century, w: Frauen in Spätantike und Frühmittelalter. Lebensbedingungen, Lebensnormen, Lebensformen, wyd. W. Affeldt, Sigmaringen 1990.

Deutinger R., Rahewin von Freising. Ein Gelehrter des 12. Jahrhunderts, Hannover 1996 (Schriften der MGH 47).

Die 'Vita sancti Heinrici regis et confessoris' und ihre Bearbeitung durch den Bamberger Diakon Adelbert, wyd. M. Stumpf, Monumenta Germaniae historica, Scriptores, t. LXIX, Hannover 1999.

Eggert W., Regna, partes regni, provinciae, ducatus. Bemerkungen zu Reichbennenungen und -auffassungen in „,deutschen” Geschichtswerken des 10. und 11. Jahrhunderts, Mitteilungen des Instituts für österreichische Geschichtsforschung 104, 1996.

Erkens F.-R., Militia und Ritterschaft. Reflexionen über die Entstehung des Rittertums, Historische Zeitschrift 258, 1994.

Fraesdorff D., Der barbarische Norden. Vorstellungen und Fremdheitskategorien bei Rimbert, Thietmar von Merseburg, Adam von Bremen und Helmold von Bosau, Berlin 2005.

Galli Anonimi Cronicae et gesta ducum sive principum Polonorum, III 2, wyd. K. Maleczyński, Monumenta Poloniae Historica, series nova, t. II, Kraków 1952.

Georgi W., Friedrich Barbarossa und die auswärtigen Mächte. Studien zur Außenpolitik 11591180, Frankfurt am Main 1990.

Gesta Frederici seu rectius chronica, wyd. A. Schmidt, F.-J. Schmale, Berlin 1965 (Ausgewählte Quellen zur deutschen Geschichte des Mittelalters. Freiherr vom Stein-Gedächtnisausgabe 17).

Giese M., Über die 'Gesta Frederici' Ottos und Rahewins von Freising. Anmerkungen zur Editions- und Überlieferungsgeschichte, Mitteilungen des Instituts für Österreichische Geschichtsforschung 119, 2011, nr 3-4.

Goetz H.-W., Das Geschichtsbild Ottos von Freising. Ein Beitrag zur historischen Vorstellungswelt und zur Geschichte des 12. Jahrhunderts, Köln 1984.

Görich K., Die Ehre Friedrich Barbarossas. Kommunikation, Konflikt und politisches Handeln im 12. Jahrhundert, Darmstadt 2001.

Grabski A. F., Polska w opiniach obcych X-XIII wieku, Warszawa 1964.

Graus, F., Böhmen zwischen Bayern und Sachsen. Zur böhmischen Kirchengeschichte des 10. Jahrhunderts, Historica 17, 1969.

Hauziński J., Polska a Królestwo Niemieckie w II połowie XII wieku, w: Polska-Niemcy w średniowieczu, Poznań 1986.

Jakubowska J., Koncepcja Koncepcja państwa i Kościoła w historiozoficznej doktrynie Ottona z Freisingu, Studia Mediewistyczne 11, 1970.

Jasiński K., Rodowód Piastów śląskich, wyd. 2, Kraków 2007.

Keller M., Konturen. Die Darstellung der Ostslawen in Chroniken und Annalen des 9.-13. Jahrhunderts, w: Russen und Rußland aus deutsche Sicht 9.-17. Jahrhundert, München 1985.

Kersken N., Das přemyslidische Böhmen in der zeitgenössischen Historiographie des Reichs, w: Böhmen und seine Nachbarn in der Přemyslidenzeit im mitteleuropäischen Vergleich, Ostfildern 2011 (Vorträge und Forschungen 74).

Koch J., Die Grundlagen der Geschichtsphilosophie Ottos von Freising, w: Geschichtsdenken und Geschichtsbild im Mittelalter, Darmstadt 1965.

Krabbo H., Eine Schilderung der Elbslawen aus dem Jahre 1108, w: Papsttum und Kaisertum. Forschungen zur politischen Geschichte und Geisteskultur des Mittelalters. Paul Kehr zum 65. Geburtstag dargebracht, München 1926. 
Kürbis B., Kształtowanie się pojęć geograficznych o Słowiańszczyźnie w polskich kronikach przeddługoszowych, Slavia Antiqua 4, 1953.

Labuda G., Mieszko II król Polski (1025-1034). Czasy przełomu w dziejach państwa polskiego, Kraków 1992.

Labuda G., O stosunkach prawnopublicznych między Polską a Niemcami w Połowie XII wieku (Merseburg - 1135, Kaina - 1146, Krzyszkowo - 1157), Czasopismo Prawno-Historyczne 25,1973 , z. 1 .

Labuda G., Źródła, sagi i legendy do najdawniejszych dziejów Polski, Warszawa 1960.

Lamperti monachi Hersfeldensis Opera, wyd. O. Holder-Egger, Scriptores rerum Germanicarum, Hannover 1894.

Lechner K., Die Babenberger, Wien 1975.

Letopis Vincenciův, wyd. J. Emler, Fontes rerum Bohemicarum, t. II, Praha 1874.

Liudprandi episcopi Cremonensis Opera omnia, wyd. J. Becker, Scriptores rerum. Germanicarum, Hannover 1915.

Lübke Ch., Regesten zur Geschichte der Slaven an Elbe und Oder (vom Jahre 900 an), t. I-V, Berlin 1984-1988.

Maleczyński K., „Sarmatae” i „Scytae” w pismach Gerberta z Aurillac, w: Europa - Słowiańszczyzna - Polska. Studia ku uczczeniu Profesora Kazimierza Tymienieckiego, Poznań 1970.

Maleczyński K., Dzieje Ryksy córki Władysława Wygnańca śląskiego, cesarzowej Hiszpanii i hrabiny Prowansji, Lwów 1933.

Maß J., Das Bistum Freising im Mittelalter, München 1986.

Morrison K. F., Otto of Freising's Quest for the Hermeneutic Circle, Speculum 55, 1980, nr 2.

Otto von Freising, w: Medieval Germany. An Encyklopedia, wyd. J. M. Jeep, New York London 2001.

Ottonis episcopi Frisingensis Chronica sive historia de duabus civitatibus, wyd. A. Hofmeister, Scriptores rerum Germanicarum, Hannover-Leipzig 1912.

Ottonis episcopi Frisingensis Chronica sive historia de duabus civitatibus, wyd. A. Schmidt, W. Lammers, Berlin 1960 (Ausgewählte Quellen zur deutschen Geschichte des Mittelalters. Freiherr vom Stein-Gedächtnisausgabe 16).

Ottonis et Rahewini Gesta Friderici I imperatoris, wyd. G. Waitz, B. von Simson, Scriptores rerum Germanicarum, Hannover-Leipzig 1912.

Petersohn J., Prawnopaństwowy stosunek Pomorza Zachodniego do państw sąsiednich w okresie średniowiecza, w: Śląsk i Pomorze w historii stosunków polsko-niemieckich w średniowieczu, Poznań 1987.

Polanský L., Přemyslovská dynastie. Soupis členů původního českého panovnického rodu, w: Přemyslovci. Budování českého státu, Praha 2009.

Radek T., Das Ungarnbild in der deutschsprachigen Historiographie des Mittelalters, Frankfut/ Main 2009.

Rüß H., Eupraxia-Adelheid. Eine biographische Annäherung, Jahrbücher für Geschichte Osteuropas 54, 2006.

Schmale F.-J., Mentalität und Berichtshorizont, Absicht und Situation hochmittelalterlicher Geschichtsschreiber, Historische Zeitschrift 226, 1978.

Schnith K., Otto von Freising, w: Lexikon des Mittelalters, t. VI, Stuttgart 2000.

Schwarzbauer F., Geschichtszeit. Über Zeitvorstellungen in den Universalchroniken Frutolfs von Michelsberg, Honorius ‘ Augustodunensis und Ottos von Freising (Orbis mediaevalis. Vorstellungswelten des Mittelalters; 6), Berlin2005.

Sobiesiak J., Od Lechowego Pola (955) do Mediolanu (1158). W służbie monarchów Rzeszy. Relacje czeskich źródeł narracyjnych o wyprawach Przemyślidów, Lublin 2011

Uebach Ch., Die Ratgeber Friedrich Barbarossas (1152-1167), Marburg 2008.

Varga G., Ungarn und das Reich vom 10. bis zum 13. Jahrhundert. Das Herrscherhaus der Árpáden zwischen Anlehnung und Emanzipation, München 2003.

Wattenbach W., Schmale F.-J., Deutschlands Geschichtsquellen, t. I, Darmstadt 1976.

Wolfram H., Konrad II. 990-1039. Kaiser dreier Reiche, München 2000.

Žemlička J., Křižovatky Vladislava II. Co mohl či nemohl druhý český král, w: Vladislav II. druhý král z Přemyslova rodu. K 850. výročí jeho korunovace, Praha 2009. 


\section{Mitteilungen Ottos von Freising und Rahewins über Polen im Vergleich zu den Nachrichten über die übrigen Nachbarn in Ost- und Mitteleuropa}

\section{Zusammenfassung}

Der vorliegende Text setzte sich zum Ziel, den Informationsgehalt der Mitteilungen zu Polen im Kontext der Nachrichten über Mittel- und Osteuropa aufzuzeigen, die in den Werken Ottos von Freising (Die Geschichte der zwei Staaten, Die Taten Kaiser Friedrichs) und des Fortsetzers seines zweiten Werkes, Rahewin, enthalten sind. Die Gegenüberstellung der Nachrichten Ottos von Freising mit denen des Rahewin über Polen zeigt, daß beiden Autoren die im Vergleich zu den Informationen über Böhmen oder Ungarn dürftige Anzahl an polnischen Betreffen gemein ist. Noch seltener wurde nur die Rus' thematisiert. Beide Autoren unterscheiden sich freilich in der Art ihrer Nachrichten über Polen. Der Freisinger Bischof schrieb außergewöhnlich lakonisch, sogar der Aufstand der Herzogsbrüder gegen seinen eigenen Schwager fand ein mehr als dürftiges Echo in seinem Werk. Rahewin wiederum faßte einen bedeutenden Bericht ab, der allerdings nicht nur dem Feldzug Friedrichs gewidmet ist. Sowohl für Otto von Freising als auch für Rahewin gehörte zwar der gesamte mitteleuropäische Raum zur christlichen, aber kulturell recht unvollkommenen Zivilisation - diese Gebiete sollten nach Meinung beider Autoren der Herrschaft des Kaisers unterstehen, der dort Recht und Ordnung einführen sollte, die bisher von den anarchischen Ureinwohnern ständig umgangen wurden. Dagegen wurde Böhmen in beiden Werken beinahe als zu einer besseren Welt zugehörig beschrieben, die dem Reich untertan war. Die Herrscher dieses Landes wurden als Partner der deutschen Könige und des deutschen Adels geachtet. Ungarn wiederum wurde schlechter beurteilt, es galt als ein vom Reich unabhängiges Königreich. Otto von Freising legte gegenüber beiden zuletzt genannten Staaten eine recht große Zurückhaltung an den Tag, Rahewin wiederum stand ihnen gewogener gegenüber. Kulturell war Polen von allen Nachbarstaaten des Reiches, das nach Meinung beider Geschichtsschreiber das Zentrum der Welt darstellte, am weitesten entfernt. Beide Chronisten wußten am wenigsten über Polen zu berichten, verdrehten seinen Namen und bezeichneten seine Einwohner unterschiedlich, sie verwechselten auch die Namen seiner Herrscher. Im Falle Polens waren sich beide Autoren uneinig, ob es dem Regnum Teutonicum (wie Otto von Freising meinte) oder aber dem Imperium Romanum (wie Rahewin andeutete) unterstehen sollte.

Übersetzt von Waldemar Könighaus

\section{Information of Otto of Freisig and Rahewin about Poland within their accounts of eastern neighbours of Germany}

\section{Abstract}

The paper discusses the information about Poland and Central Europe contained in the History of two states and Acts of Frederic. Otto wrote laconic notes, while Rahewin created a relation on Frederic's expedition to Poland in 1157. For both of them that region was culturally inferior: those lands should be subordinated to the Reich rulers who had the right to introduce order there. Bohemia was considered the best, because its rulers were partners of German kings. Hungary was perceived as worse, especially by Otto. Poland was the least known country. In its case there was a controversy whether it should be dependent on Regnum Teutonicum or Imperium Romanum. 